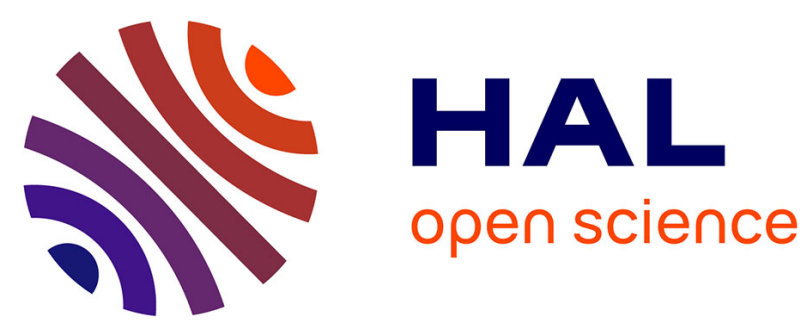

\title{
Mechanochemical Preparation of 3,5-Disubstituted Hydantoins from Dipeptides and Unsymmetrical Ureas of Amino Acid Derivatives
}

Laure Konnert, Lori Gonnet, Ivan Halasz, Jean-Simon Suppo, Renata Marcia

de Figueiredo, Jean-Marc Campagne, Frederic Lamaty, Jean Martinez, Evelina Colacino

\section{To cite this version:}

Laure Konnert, Lori Gonnet, Ivan Halasz, Jean-Simon Suppo, Renata Marcia de Figueiredo, et al.. Mechanochemical Preparation of 3,5-Disubstituted Hydantoins from Dipeptides and Unsymmetrical Ureas of Amino Acid Derivatives. Journal of Organic Chemistry, 2016, 81 (20), pp.9802-9809. 10.1021/acs.joc.6b01832 . hal-01396871

\section{HAL Id: hal-01396871 \\ https://hal.science/hal-01396871}

Submitted on 29 Jan 2021

HAL is a multi-disciplinary open access archive for the deposit and dissemination of scientific research documents, whether they are published or not. The documents may come from teaching and research institutions in France or abroad, or from public or private research centers.
L'archive ouverte pluridisciplinaire HAL, est destinée au dépôt et à la diffusion de documents scientifiques de niveau recherche, publiés ou non, émanant des établissements d'enseignement et de recherche français ou étrangers, des laboratoires publics ou privés. 


\title{
Mechanochemical Preparation of 3,5-Disubstituted Hydantoins from Dipeptides and Unsymmetrical Ureas of Amino Acid Derivatives
}

\author{
Laure Konnert, $^{\dagger}$ Lori Gonnet, $^{\dagger}$ Ivan Halasz, $^{\ddagger}$ Jean-Simon Suppo, ${ }^{\S}$ Renata Marcia de Figueiredo, ${ }^{\S}$ \\ Jean-Marc Campagne, ${ }^{\S}$ Fredéric Lamaty, ${ }^{\dagger}$ Jean Martinez, ${ }^{\dagger}$ and Evelina Colacino ${ }^{*},^{\dagger}$ \\ ${ }^{\dagger}$ Université de Montpellier, Institut des Biomolécules Max Mousseron UMR 5247 CNRS, ENSCM, Place E. Bataillon,
Campus Triolet, cc 1703, 34095 Montpellier, France
${ }^{\ddagger}$ Ruđer Bošković Institute, Bijenička cesta 54, Zagreb, Croatia
${ }^{\S}$ Institut Charles Gerhardt Montpellier (ICGM), UMR 5253 CNRS-UM-ENSCM, Ecole Nationale Supérieure de Chimie,
8 Rue de l’Ecole Normale, 34296 Montpellier Cedex 5, France
}

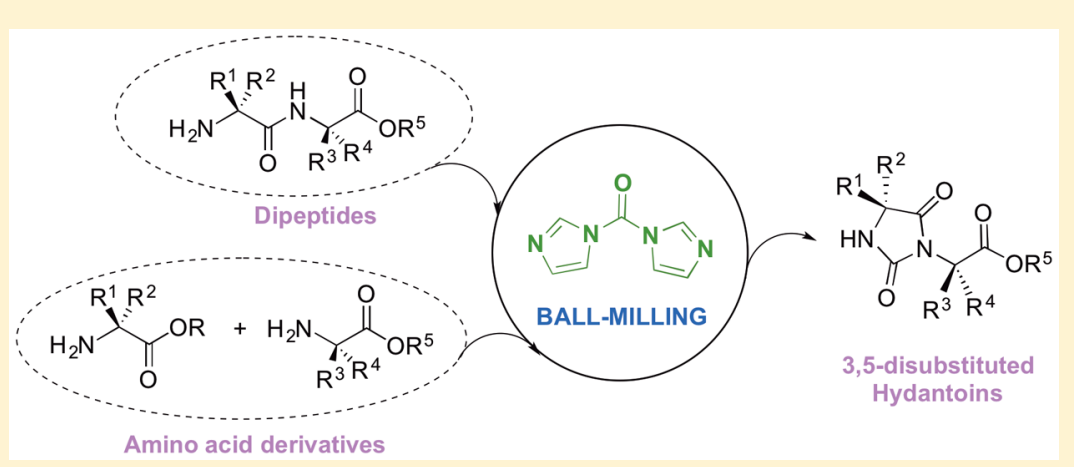

ABSTRACT: 5-Substituted-3-(alkoxycarbonyl)alkyl-hydantoin derivatives were prepared by mechanochemistry from amino esters or dipeptides, via a 1,1'-carbonyldiimidazole-mediated one-pot/two-step cyclization reaction involving amino acid unsymmetrical urea $\mathbf{A}$ and carboxy-imidazolyl-dipeptide ester $\mathbf{B}$ intermediates. Comparative experiments in solution were also performed. The successful preparation of an antibacterial agent precursor was also investigated.

\section{INTRODUCTION}

Compounds containing the 2,4-imidazolidinedione scaffold are a well-known family of bioactive products (hydantoin family) with numerous therapeutic properties (also pesticides). ${ }^{1}$ The hydantoin core offers numerous possibilities of substitutions, allowing building a large diversity of potential structures. In particular, 5-substituted-3-(alkoxycarbonyl)alkyl-hydantoin derivatives (Figure 1) present a particular substitution pattern, which make them interesting peptidomimetics ${ }^{2}$ and bioactive compounds with antiepileptic, anticonvulsant, antiarrhythmic, or antibacterial properties. ${ }^{1,3-5}$ They have been notably presented as inhibitors of dihydro-orotate dehydrogenase from Clostridium (Zymobacterium) oroticum for the potential treatment of parasitic diseases. ${ }^{6,7}$

From the synthetic point of view, these structures have been often reported as byproducts in peptide synthesis. ${ }^{8-11}$ However, their structural and biological interests have given rise to the development of several methodologies for their preparation. The reaction of amino acid derivatives with isocyanates led to the formation of such hydantoins, after cyclization of the corresponding ureido derivatives in strong acidic conditions $^{5,12,5,13}$ (Figure 1a). $N$-alkylation with halogeno acetates and their derivatives, ${ }^{14,7,15,16}$ and Michael addition ${ }^{17}$ reactions, allowed the introduction of the carboxyalkyl group at the $N-3$ position of hydantoins, with a particular interest in phenytoin derivatives $^{3,18-20,4,17}$ (Figure 1b). Miscellaneous procedures reported the reaction between acetylenic diesters and isocyanides, ${ }^{21}$ or phosphates, ${ }^{22}$ in the presence of an hydantoin molecule (Figure 1b). The rearrangement of Boc-protected dipeptide compounds, ${ }^{23}$ diketopiperazines, ${ }^{24}$ seven-membered cyclopeptides, ${ }^{25}$ and oxazolidinones ${ }^{26}$ were also described (Figure 1c).

Due to our ongoing work on the use of mechanochemistry for the preparation of carbamates from amino acid derivatives, ${ }^{27-29}$ and biologically relevant compounds by grinding in a ballmill, ${ }^{29,30,31}$ it seemed appealing to develop mechanochemical strategies to access 5-substituted-3-(alkoxycarbonyl)-alkyl-hydantoins. Specifically, our previously developed procedure on the $1,1^{\prime}$-carbonyldiimidazole (CDI)-mediated mechanochemical synthesis of 3,5-disubstituted hydantoins ${ }^{31}$ might be applicable to the preparation of similar structures, via a one-pot/two-step cyclization reaction involving amino acid unsymmetrical urea $\mathbf{A}$ (Method A) or a carboxy-imidazolyl-dipeptide ester B (Method B) (Scheme 1).

To the best of our knowledge, Strukil et al. ${ }^{32-35}$ achieved the only described mechanochemical preparation of unsymmetrical (thio)ureas from either iso(thio)cyanates or benzotriazolyl-activated 


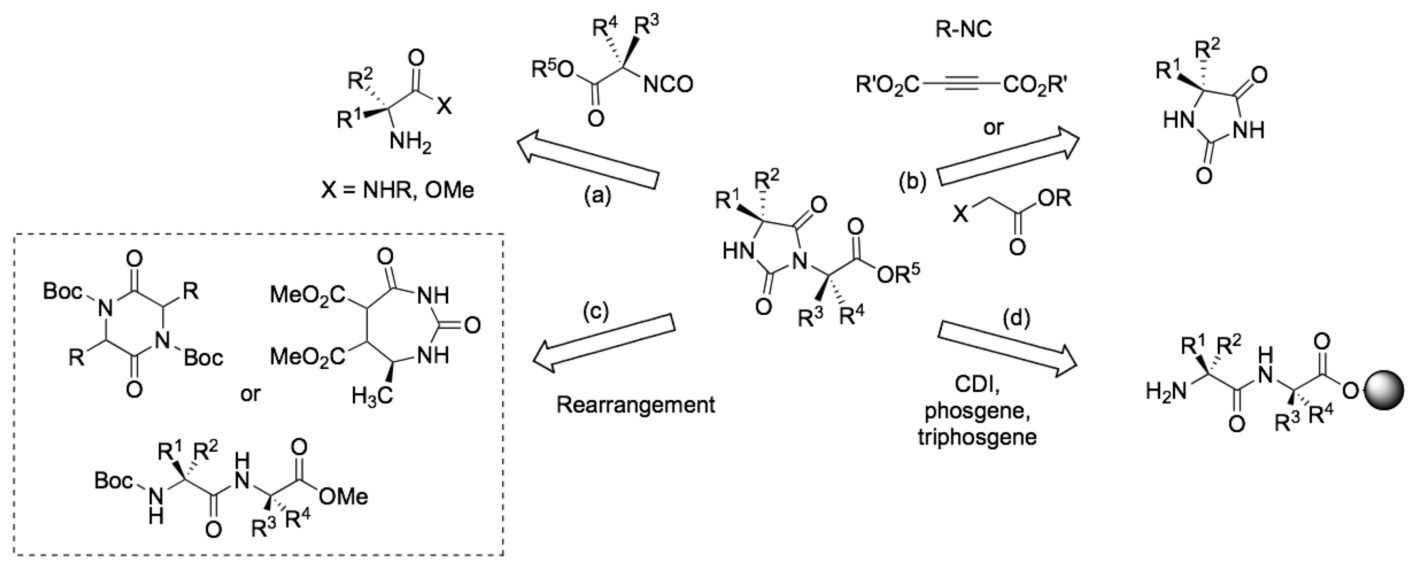

Figure 1. 5-substituted-3-(alkoxycarbonyl)alkyl-hydantoin structures.

Scheme 1. Synthesis of 5-Substituted-3-(alkoxycarbonyl)alkyl-hydantoins by Mechanochemistry

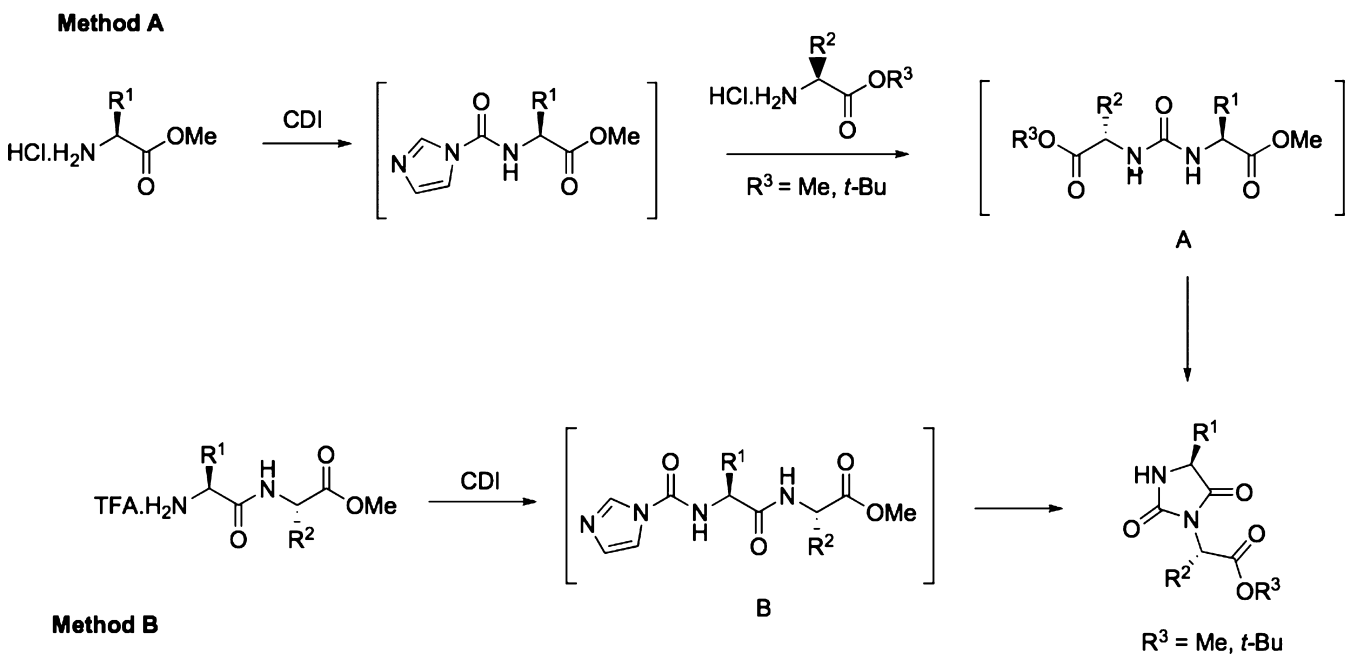

thiocarbonyls. ${ }^{32}$ In solution, thiohydantoins were prepared from dissymmetrical thioureas derived from amino acids. ${ }^{36,37}$ We have described the synthesis of unsymmetrical ureas containing one amino ester, from either potassium cyanate ${ }^{30,29}$ or isocyanates, ${ }^{31}$ but no mechanochemical desymmetrization from amino acid urea derivatives and using CDI as an activating agent has been reported so far. In solution, CDI has been used for the preparation of symmetrical $^{6}$ and unsymmetrical ${ }^{38,39}$ ureas from amino acid derivatives. However, these synthetic methods often require the use of toxic solvents such as DMF, the use of a base such as triethylamine, and extra reagents such as methyl trifluoromethanesulfonate $e^{40,39}$ to enhance the reactivity of the carboxamido intermediate.

Amino acid ureas have been reported to cyclize into hydantoins in the presence of concentrated $\mathrm{HCl}^{6,41}$ In only one case the symmetrical urea was formed when using CDI. ${ }^{6}$ So far, no study has reported on the preparation of hydantoins from dissymmetrical ureas obtained from amino acid derivatives and the safe, cheap, and easy-to handle CDI (Scheme 1, method A), neither in solution nor by mechanochemistry. Furthermore, mechanochemical reaction conditions avoid the use of solvents and provide a strong activation in reactions involving $\mathrm{CDI},{ }^{29}$ thus avoiding the addition of extra base or activating agents to the reaction mixture.

Another possible strategy to prepare 5-substituted-3-(alkoxycarbonyl)-alkyl-hydantoins under ball-milling conditions was to explore the reactivity of CDI toward dipeptides, instead of single amino esters, (Scheme 1, method B). Liu et al. reported the rearrangement of $N$-Boc-dipeptides into the corresponding hydantoins in solution, in the presence of triflic anhydride. ${ }^{23} \mathrm{On}$ solid support, the preparation of hydantoins proceeded through the formation of an isocyanate function on resin-bound peptides. This isocyanate could be generated after removal of the Fmocprotecting group from the $N$-terminal moiety of the peptide, ${ }^{42}$ but more generally by nucleophilic attack of this amino moiety on the triphosgene ${ }^{43,44}$ or CDI-activated ${ }^{45,9}$ carbonyl of the carboxylic function.

The mechanochemical pathway is an interesting alternative to solid-phase synthesis, for which the scale-up would be quite difficult (Figure 1d). We report herein two unprecedented mechanochemical synthetic routes to access 5-substituted-3(alkoxycarbonyl)alkyl-hydantoins. The first one consists of the synthesis of unsymmetrical ureas (A) from amino esters and $\mathrm{CDI}$ and their one-pot cyclization into the targeted hydantoins (Scheme 1, method A). The second one describes the CDI activation of $N$-terminal moieties of dipeptides followed by cyclization (Scheme 1, method B). The disclosed methodology is a valid eco-friendly alternative (replacing the use of triphosgene) ${ }^{46}$ to prepare 5-benzyl-3-(methyloxycarbonyl)benzyl hydantoin 2e (Table 2, entry 5), which the corresponding carboxylic acid is an antiparasite agent, inhibitor of dihydro-orodotase dehydrogenase from Clostridium (Zymobacterium) oroticum. ${ }^{6,7}$ 


\section{RESULTS AND DISCUSSION}

Synthesis of 3-Substituted Alkoxycarbonyl Hydantoins from Unsymmetrical Ureas of Amino Esters (Method A). We have recently reported the CDI-mediated mechanochemical preparation of $\mathrm{N}$-protected carbamates of amino esters ${ }^{29}$ and 3,5-dialkyl substituted hydantoins, ${ }^{31}$ in a planetary ball-mill (PBM). Relying on our precedent one-pot/ two-step procedure, an amino ester hydrochloride $\mathbf{A A}_{\mathbf{1}}$ was reacted with $\mathrm{CDI}$, leading to the corresponding $1 \mathrm{H}$-imidazolecarboxamido intermediate (first step) (Table 1). Milling the mixture in the presence of $\alpha$ - or $\beta$-amino tert-butyl esters $\mathbf{A A}_{2}$, added in the second step, led to dissymmetrical carbonyl diamino esters 1, that were smoothly converted into hydantoins by a chemoselective base-mediated intramolecular cyclization (Tables 1 and 2). Therefore, formation of regioisomeric hydantoins could be avoided when cyclizing either by one-pot generated symmetrical carbonyl diamino esters or by means of a one-pot stepwise addition to the grinding jar containing methyl/tert-butyl esters (Table 1).

Strictly applying the previously described experimental conditions to the synthesis of 5-benzyl-3-(tert-butoxycarbonyl)isobutyl-hydantoin 2a led to only moderate yields; the cyclization of the unsymmetrical urea 1a was incomplete (entry 1). Switching the addition order of the amino esters did not significantly improve the reaction yield (entry 2 ), however, it was increased to $63 \%$ when the second step of the reaction was carried out for $4 \mathrm{~h}$ at $450 \mathrm{rpm}$ (entry 3 ). From this preliminary optimization, several combinations of amino methyl and tert-butyl esters were tested to scope the variety of substrates. Most of the corresponding hydantoins were obtained in satisfying to good yields (Table 2), with the exception of $\mathbf{2 b}$ and $2 \mathrm{e}$ (entries 2 and 5). The grinding parameters were found to be essential. Indeed, whereas good yields were obtained with $\mathbf{2 a}$, $2 c$, and $2 \mathrm{~d}$ in a PBM, while no or low conversion was observed in the case of $\mathbf{2 b}$ and $\mathbf{2 e}$. Regardless of the milling parameters set for PBM, the cyclization reaction into hydantoin $\mathbf{2 b}$ could not be improved, and the yield remained moderate. Indeed, the cyclization reaction led to a mixture of the symmetrical carbonyl diamino methyl ester of valine (urea formed in the first step) and the corresponding dissymmetrical urea $\mathbf{1} \mathbf{b}$ (formed in the second step), both structures attributed to the base of LC/MS analyses of the crude mixture. The best results were obtained using the PBM for $2 \mathrm{~h}$ (entry 2). It is noteworthy that the procedure was applicable to quaternary amino esters (entry 3 ) as well as to $\beta$-amino acid derivatives (entry 4 ) from which the hydantoin $\mathbf{2 d}$ was recovered in $88 \%$ yield. The preparation of $\mathbf{2 e}$, issued from the symmetrical urea of phenylalanine methyl ester, could also be achieved in a satisfying yield of $58 \%$ using VBM (entry 5). The yield was not improved by extending the reaction time up to $6 \mathrm{~h}(52 \%$, entry 5$)$ or by changing the base. When $\mathrm{Na}_{2} \mathrm{CO}_{3}, \mathrm{NaHCO}_{3}$, and triethylamine were used instead of $\mathrm{K}_{2} \mathrm{CO}_{3}$, conversion of the starting amino ester was not complete, and the cyclization reaction failed. Disappointingly, it was not possible to prepare hydantoin $2 \mathrm{e}$ by performing the reaction in a PBM for $4 \mathrm{~h}$. Cyclization did not occur, and only the corresponding symmetrical urea $\mathbf{1}$ was obtained, confirming that PBM was not suitable to prepare $2 \mathbf{e}$ hydantoin, probably due to the sticky texture of the milling mixture. Results were not improved when variable quantities of inert grinding additives, such as $\mathrm{NaCl}^{47-49}$ were added to modify the mechanical properties of the mixture. As previously experimented for other organic transformations, ${ }^{29,28}$ the differences in grinding phenomena and parameters occurring in the PBM with respect to VBM could be the explanation. Noteworthy, the carboxylic acid of compound $2 \mathrm{e}$ is a dihydro-orotate dehydrogenase inhibitor ${ }^{6}$ and thus may be easily obtained from 2e. The workup of the reaction was very simple, as the products were recovered by precipitation/filtration by addition of water to the crude mixture in the milling jar $(\mathbf{2} \mathbf{a}, \mathbf{2} \mathbf{d}$, and $\mathbf{2 e})$ or by extraction in ethyl acetate $(\mathbf{2 b}$ and $\mathbf{2 c})$.

Synthesis of 3-Substituted Alkoxycarbonyl Hydantoins from Dipeptides (Method B). Several TFA salts of dipeptide methyl esters 3 were synthesized following usual procedures in solution. ${ }^{50}$ Then, they were reacted with CDI in a PBM in neat conditions without base. As described above, the reaction consisted of the nucleophilic attack of the free

Table 1. Optimization of the Reaction Conditions for the Preparation of 5-Substituted-3-(alkoxycarbonyl)alkyl-hydantoins ${ }^{a}$

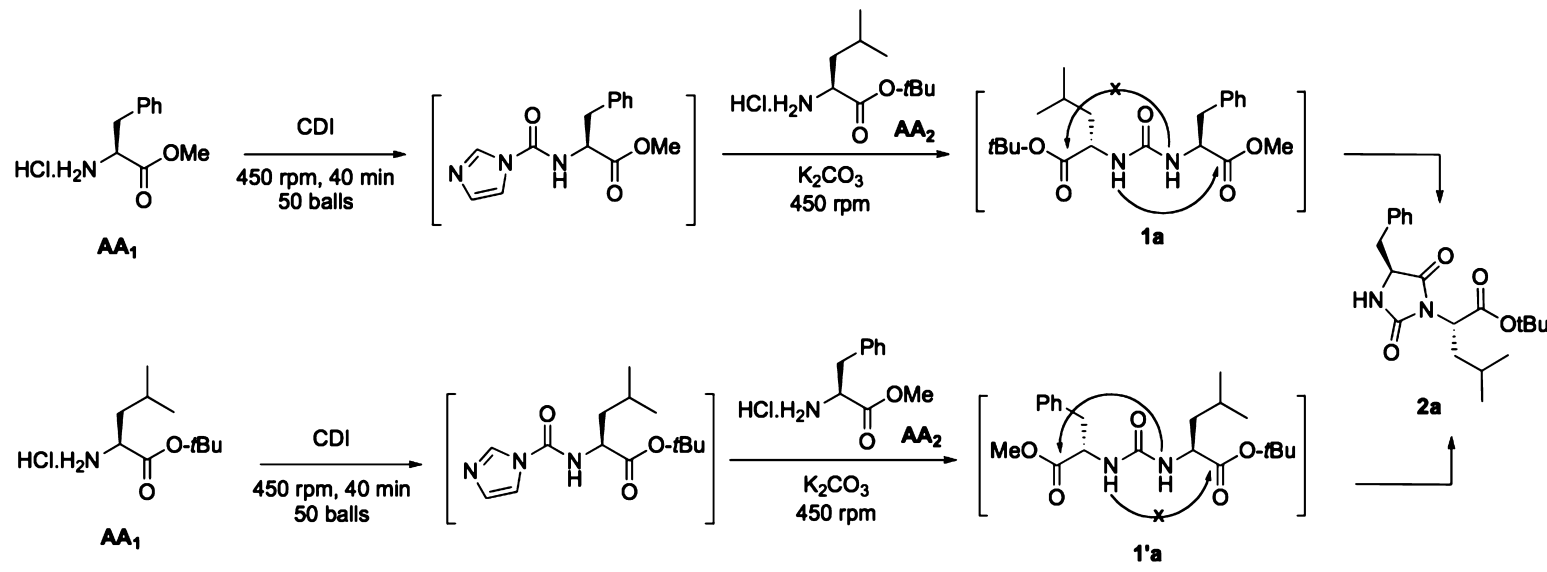

\begin{tabular}{cl}
\hline entry & $\mathrm{AA}^{b}$ derivative 1 \\
1 & $\mathrm{HCl} \cdot \mathrm{H}-\mathrm{Phe}-\mathrm{OMe}$ \\
2 & $\mathrm{HCl} \cdot \mathrm{H}-\mathrm{Leu}-\mathrm{O} \mathrm{Bu}$ \\
3 & $\mathrm{HCl} \cdot \mathrm{H}-\mathrm{Phe}-\mathrm{OMe}$
\end{tabular}

$\begin{array}{cc}\mathrm{AA}^{b} \text { derivative } 2 & \text { reaction time (step 2) (h) } \\ \mathrm{HCl} \cdot \mathrm{H}-\mathrm{Leu}-\mathrm{O} t \mathrm{Bu} & 2 \\ \mathrm{HCl} \cdot \mathrm{H}-\mathrm{Phe}-\mathrm{OMe} & 3 \\ \mathrm{HCl} \cdot \mathrm{H}-\mathrm{Leu}-\mathrm{O} t \mathrm{Bu} & 4\end{array}$

yield $(\%)^{c} \mathbf{2 a}$

40

47

63

${ }^{a}$ Conditions: (Step 1) L- $\alpha$-amino ester $\mathbf{A A}_{\mathbf{1}}$ (1 equiv) and CDI (1.3 equiv) at $450 \mathrm{rpm}, 50$ balls ( $5 \mathrm{~mm}$, stainless steel, $5 \mathrm{~mm} \emptyset$ ) for $40 \mathrm{~min}$; (step 2 ) $\mathrm{L}-\alpha$-amino ester $\mathrm{AA}_{2}$ (1.6 equiv) and $\mathrm{K}_{2} \mathrm{CO}_{3}$ (3.6 equiv) at $450 \mathrm{rpm} .{ }^{b} \mathrm{AA}=$ Amino acid. ${ }^{c}$ Yield of isolated compounds. 
Table 2. Synthesis of 5-Substituted-3-(alkoxycarbonyl)alkyl-hydantoins from Ureas of Amino Esters

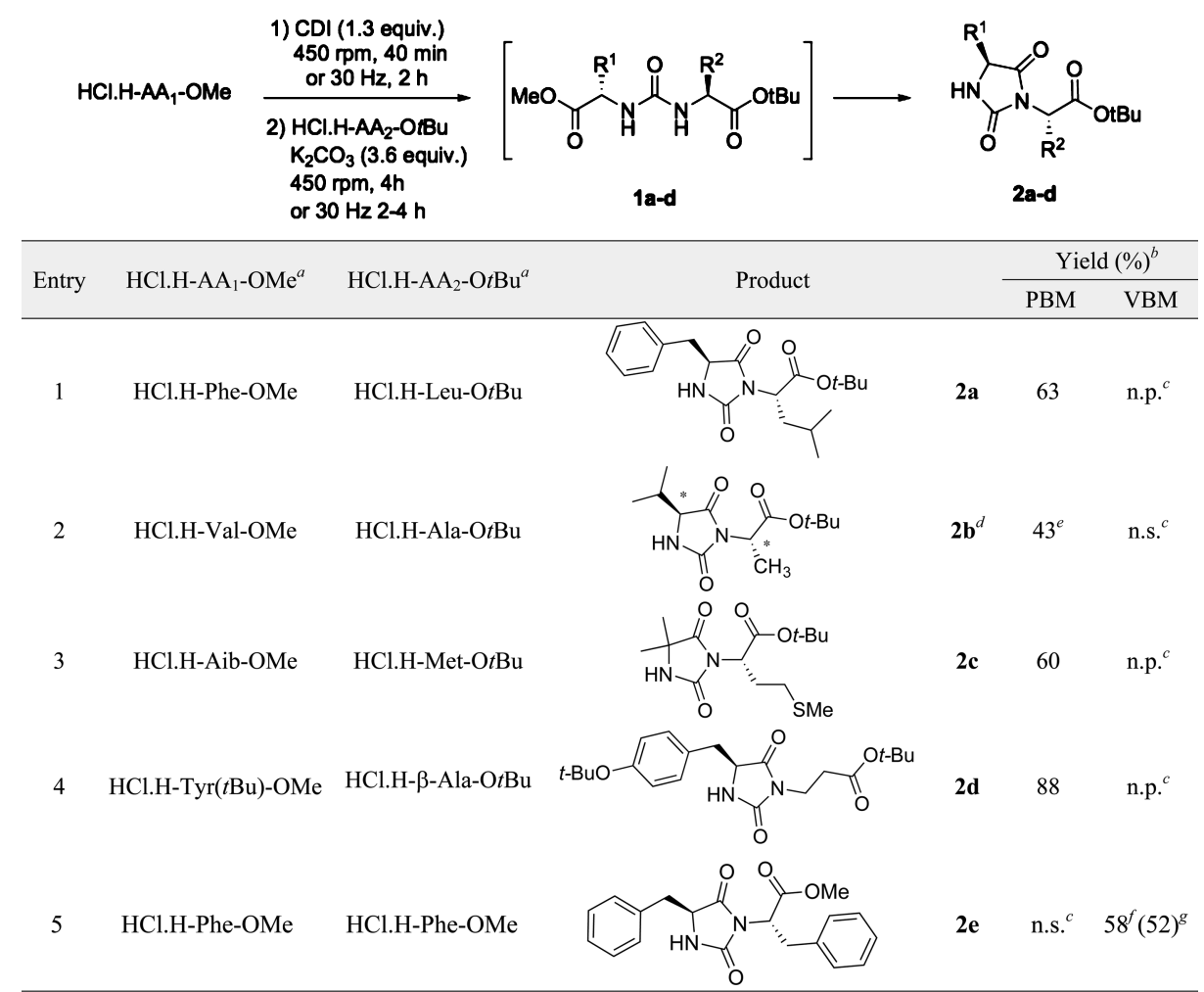

${ }^{a}$ The amino esters were of L-configuration. ${ }^{b}$ Isolated yields. ${ }^{c}$ n.p. $=$ not performed, n.s. $=$ not successful. ${ }^{d}$ Mixture of diastereoisomers $($ dr $57: 43)$ determined by ${ }^{1} \mathrm{H}$ NMR. ${ }^{e}$ The second step was performed for $2 \mathrm{~h}$ only. ${ }^{f}$ Conditions: $\mathrm{HCl} \cdot \mathrm{H}-\mathrm{Phe}-\mathrm{OMe}\left(2\right.$ equiv), $\mathrm{CDI}\left(1\right.$ equiv) and $\mathrm{K}_{2} \mathrm{CO}_{3}$ ( 3 equiv) were milled in a VBM at $30 \mathrm{~Hz}$ for $2 \mathrm{~h} .{ }^{g}$ Yield is given for $6 \mathrm{~h}$ reaction in the VBM.

$N$-terminal moiety of the peptides, on the CDI activated carboxylic acid group, to afford activated $1 \mathrm{H}$-imidazolecarboxamido species $\mathbf{4}$ that cyclized directly into the hydantoins. At this stage, we wondered if the intermediate of the reaction was either the $1 \mathrm{H}$-imidazolyl carboxamido derivative 4 (Table 3) or the corresponding isocyanate, generated in similar procedures in solution. ${ }^{51}$ Indeed, mechanochemistry is known to induce, in some cases, different reactivities than in the corresponding reactions in solution. By in situ Raman spectroscopy, it was recently demonstrated that the mechanochemical reaction between anilines and bis(benzotriazolyl)methanethione afforded the aryl $N$-thiocarbamoylbenzotriazoles that could be isolated, species that decompose instantly into isocyanates in solution synthesis. $^{32}$ By analogy to the benzotriazole intermediates, we assumed that the reaction went through the formation of intermediate 4 . Once the $1 \mathrm{H}$-imidazole-carboxamido intermediate 4 was formed, the intramolecular nucleophilic attack of the amide peptide bond on the $C$-activated imidazolyl carboxamide led to an intramolecular cyclization reaction to produce hydantoins 5, never described so far (Table 3).

The corresponding hydantoins were readily obtained in good yields under nonoptimized conditions (Scheme 1). The only byproducts of the reaction identified were the symmetrical urea of the dipeptides. Indeed, in the first trial, consisting of the milling of TFA.H-Phe-Leu-OMe with 2 equiv of CDI at $450 \mathrm{rpm}$ for $2 \mathrm{~h}$, the hydantoin 5 a was obtained in $82 \%$ yield (entry 1 ). NMR of the crude showed the presence of the dipeptide urea in $8 \%$ yield compared to the desired compound. A shorter time of $1 \mathrm{~h}$ milling decreased the yield of 5 a to $76 \%$ (entry 1 ), while no improvement was observed when extending the milling time to $6 \mathrm{~h}$ (entry 2 ) for compound $\mathbf{5 b}$. The reactions were performed for $2 \mathrm{~h}$ using dipeptide methyl esters $3 \mathbf{b}-\mathbf{e}$ or the amide $\mathbf{3 f}$ (entries 2-6). It could be noticed that cyclization of the postulated intermediates 4 occurred without the need of a base, in contrast with solid-phase synthesis. ${ }^{45}$ Indeed, when prepared in solution, the intermediate $4 \mathrm{c}$ proved to be very unstable and difficult to isolate, undergoing fast cyclization into hydantoin $\mathbf{5 c}$. Based on our previous findings, ${ }^{29}$ we excluded an autocatalyzed/ base regenerating system, promoting the cyclization, despite the presence of 1 equiv of imidazole, generated in the mixture after the first step. Indeed, the strong activation provided by mechanochemistry allowed the direct reaction of a non-nucleophilic dipeptide (HX salt) 3 with CDI (without the need of a base to generate in situ a free amine). It is proposed that two sequential acid-base reactions were the driving force of the reaction, leading to intermediates $\mathbf{A}$ and postulated $\mathbf{B}$, each having the distal nitrogen of the imidazole nucleus activated by protonation (Scheme 2).

Mechanochemistry allowed the preparation of hydantoins 5 in slightly shorter reaction times $(2 \mathrm{~h})$ compared to solution-based protocols ( $4 \mathrm{~h}$ under stirring), and with no need to further activate the reactants. Generally, the yields were higher under mechanochemistry, and the purification of the crude was easier. Moreover, the reaction was versatile, as dipeptides with various side chains and $C$-terminal functions (Table 3, 3f, entry 6) were transformed into hydantoins. Product 5 f was obtained in a $29 \%$ NMR yield, but we did not succeed in its purification from the imidazole (entry 6). IR experiments confirmed that hydantoins 5 had been obtained, instead of dipeptide isocyanates, which can be prepared from phosgene or triphosgene in solution. ${ }^{51}$ The typical absorbance band at $2270 \mathrm{~cm}^{-1}$ was not detectable in the crude, confirming the formation of the desired hydantoins, which 
Table 3. Preparation of 5-Substituted-3-(alkoxycarbonyl)alkyl-hydantoins from Dipeptides

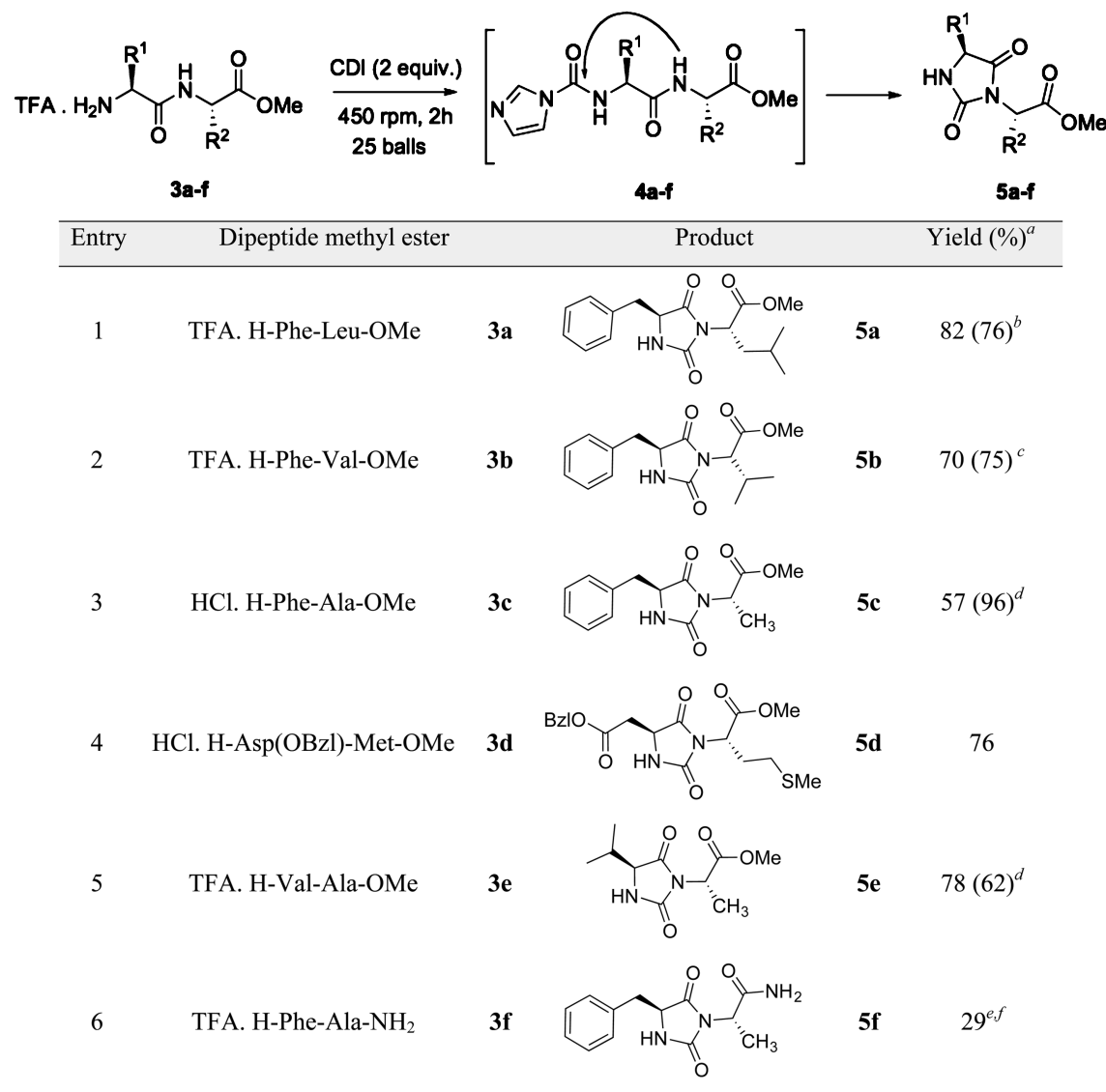

${ }^{a}$ Isolated yields. ${ }^{b}$ Yield after $1 \mathrm{~h}$ milling. ${ }^{c}$ Yield is given for $6 \mathrm{~h}$ reaction in the PBM. ${ }^{d}$ Yield is given for synthesis in solution. ${ }^{e 1} \mathrm{H}$ NMR yield. ${ }^{f}$ Full conversion by LC/MS analyses for synthesis in solution.

\section{Scheme 2. Proposed Mechanism to Hydantoins 5}<smiles>[R]C([NH3+])C(=O)NC([R])C(=O)OC</smiles>

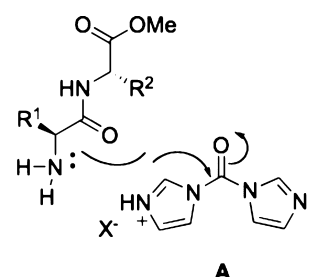<smiles>CC(C)CC1CCCCC1</smiles>

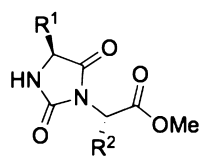

5

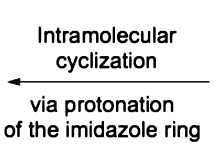

of the imidazole ring

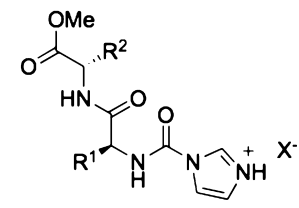

B is in contrast with previous reports reporting formation of stable isocyanates in solution.

Method B was also applied to the preparation of compound 2e from TFA.H-Phe-Phe-OMe, for sake of comparison with the solution procedure usually carried out in harsh conditions (triphosgene and pyridine under reflux for $12 \mathrm{~h}$ ). ${ }^{46}$ By mechanochemistry, the cyclization according to Method B was not possible, with or without a base, and by modifying the milling parameters (e.g., extending the reaction time or increasing the number of milling balls). It is acknowledged that new compounds or novel reactivities can be accessed using mechanochemistry, because different energetic (and mechanistic) pathways are involved compared to the synthesis in solution. In this particular case, mechanochemistry failed where solution chemistry was successful. As a consequence, the preparation of hydantoin $2 \mathbf{e}$ according to our initial approach (Method A) remained the only new and alternative route to this compound by mechanochemistry.

Overall, our procedure presented a number of advantages also over the described solid-phase synthesis: (1) ball-milling allowed a solvent-free reaction that avoids the use of toxic DMF; (2) no extra base was required as the hydantoins were readily obtained by the simple mechanochemical reaction between dipeptides and $\mathrm{CDI}$; (3) the postulated intermediates 4 did not require any activation by extra reagents; (4) only 2 equiv of CDI were required, which is much less than in solution reaction; ${ }^{44,45}$ and finally (5) ball-milling provides a cheaper alternative and possible scale-up of the reaction compared to solid-phase synthesis, which was the only reported pathway for the preparation of the desired hydantoins from dipeptides. These five points support the use of mechanochemistry to prepare hydantoins with less waste production, for a more sustainable and environmental green chemistry.

\section{CONCLUSIONS}

We presented here two methodologies for the preparation of new structures of 5-substituted-3-(tert-butoxycarbonyl)alkylhydantoins, belonging to a class of biologically active molecules, 
by mechanochemistry. In the first part, we described a novel procedure in which unsymmetrical ureas prepared from amino esters were cyclized into the corresponding hydantoins (Method A). In the second part, we presented an improved and a more environmental-friendly procedure for the synthesis of hydantoins by intramolecular cyclization of dipeptides (Method B). The key reagent of these synthetic methods was $1,1^{\prime}$-carbonyldiimidazole (CDI), which enabled the activation of the amino functionality of dipeptides and amino acid derivatives. The syntheses required no or few optimization, allowed the use of various substrates, afforded the new compounds in good yields, and were carried out following a more sustainable synthetic route brought about by the ball-milling technology. Moreover, compared to the previously reported methods in solution, both methodologies displayed higher atom and solvent economy, also overcoming the $N-1 / N-3$ regioselectivity problems usually encountered in alkylation reactions of hydantoins. ${ }^{16}$ From a more general perspective, this work contributes to advance an area recently termed as medicinal mechanochemistry, ${ }^{52}$ with the emergence and the development of mechanochemical techniques for the preparation of API, ${ }^{48,53,35}$ opening new trends and perspectives for the pharmaceutical industry, in "thinking chemistry differently".

\section{EXPERIMENTAL SECTION}

General Remarks. All reagents were commercially available and used without any further purification. $\mathrm{L}-\alpha$-amino esters were used. TFA salts of dipeptide methyl esters were synthesized following usual procedures in solution. ${ }^{50}$ NMR spectra were recorded at room temperature with the appropriate deuterated solvent $\left(\mathrm{CDCl}_{3}\right.$ or $d_{6}$-DMSO). Chemical shifts $(\delta)$ of ${ }^{1} \mathrm{H}$ NMR and ${ }^{13} \mathrm{C}$ NMR spectra are reported in $\mathrm{ppm}$ relative to residual solvent signals $\left(\mathrm{CHCl}_{3}\right.$ in $\mathrm{CDCl}_{3}: \delta=7.27 \mathrm{ppm}$ for ${ }^{1} \mathrm{H}$ and $\mathrm{CDCl}_{3}: \delta=77.04 \mathrm{ppm}$ for $\left.{ }^{13} \mathrm{C} \mathrm{NMR}\right) . J$ values are given in $\mathrm{Hz} .{ }^{1} \mathrm{H}$ and ${ }^{13} \mathrm{C}$ NMR spectra were registered at 300 $\mathrm{MHz}$ and $400 \mathrm{MHz}$. HRMS measurements were performed on a TOF mass analyzer. Melting points were measured on a Büchi Melting Point 510 apparatus (or M-560 for compound 5c) and are uncorrected. Infrared spectra were recorded on a FT-IR spectrometer equipped with high-pressure diamond cell. Optical rotation for compounds $2 a-e$ and $5 \mathbf{a}-\mathbf{e}$ was measured in $\mathrm{CHCl}_{3}$ at $\lambda=589 \mathrm{~nm}$ ( Na lamp). Analytical highperformance liquid chromatography (HPLC) was performed with a variable-wavelength diode detector using a CHROMOLITH RP18 column $(50 \times 4.6 \mathrm{~mm})$, flow $5 \mathrm{~mL} / \mathrm{min}$, linear gradient $\mathrm{CH}_{3} \mathrm{CN}$ in water $0-100 \%(+0.1 \% \mathrm{TFA})$ in $4.5 \mathrm{~min}$. LC-MS analyses were performed with HPLC, column Onyx $\mathrm{C}_{18},(25 \times 4.6 \mathrm{~mm})$, flow $3 \mathrm{~mL} / \mathrm{min}$ linear gradient $\mathrm{CH}_{3} \mathrm{CN}$ in water $0-100 \%\left(+0.1 \% \mathrm{HCO}_{2} \mathrm{H}\right)$ in $2.5 \mathrm{~min}$. The ball-milling experiments were performed in a vibrational ball using $5 \mathrm{~mL}$ mill steel jar ( 2 stainless steel balls, $5 \mathrm{~mm} \varnothing)$ and in a planetary mill, $12 \mathrm{~mL}$ steel jar ( 25 or 50 stainless steel balls, $5 \mathrm{~mm} \emptyset$ ).

General Procedure for the Synthesis of 5-Substituted-3-(tertbutoxycarbonyl)alkyl-hydantoins (Method A). Conditions in a PBM (Compounds $\mathbf{2 a}-\mathbf{d}$ ): The amino acid methyl ester (1 equiv) and CDI (1.3 equiv) were added to a $12 \mathrm{~mL}$ stainless steel milling jar with 50 stainless steel milling balls ( $5 \mathrm{~mm}$ diameter). The reactants were milled for $40 \mathrm{~min}$ at $450 \mathrm{rpm}$. The amino acid tert-butyl ester (1.6 equiv) and $\mathrm{K}_{2} \mathrm{CO}_{3}$ (3.6 equiv) were added to the jar, and the reaction mixture was milled for $4 \mathrm{~h}$ at $450 \mathrm{rpm}$. Conditions in a VBM (Compound 2e): A $5 \mathrm{~mL}$ stainless steel milling jar with 2 stainless steel milling balls $(5 \mathrm{~mm}$ diameter) were used at $30 \mathrm{~Hz}$ for the specified time (Table 1). Distilled water was added to the jar, and the desired compounds precipitated. They were recovered either by filtration $(\mathbf{2} \mathbf{a}, \mathbf{d})$ or by extraction of the aqueous layer with ethyl acetate $(\mathbf{2} \mathbf{b}, \mathbf{c})$. The organic layer was washed three times with $10 \%$ aq. citric acid and brine, dried over anhydrous $\mathrm{MgSO}_{4}$ and concentrated in vacuo. The crude compounds $\mathbf{2 a}-\mathbf{c}$ were further purified by column chromatography (linear gradient of EtOAc in cyclohexane from 0 to $20 \%$ ).

(S)-tert-Butyl 2-((S)-4-Benzyl-2,5-dioxoimidazolidin-1-yl)-4-methylpentanoate $2 a$ (Table 2, Entry 1). The reaction scale was $0.83 \mathrm{mmol}$
(188.3 mg, 63\% yield). White solid, mp $160-162{ }^{\circ} \mathrm{C},[\alpha]_{\mathrm{D}}^{28}-8.77$ $\left(c=5.2, \mathrm{CHCl}_{3}\right) ;{ }^{1} \mathrm{H}$ NMR $\left(300 \mathrm{MHz}, \mathrm{CDCl}_{3}\right) \delta(\mathrm{ppm}): 7.34-7.19$ $(\mathrm{m}, 5 \mathrm{H}), 5.90(\mathrm{~s}, 1 \mathrm{H}), 4.56(\mathrm{dd}, J=11.5 \mathrm{~Hz}, J=4.4 \mathrm{~Hz}, 1 \mathrm{H}), 4.28(\mathrm{dd}, J$ $=8.0 \mathrm{~Hz}, J=3.3 \mathrm{~Hz}, 1 \mathrm{H}), 3.28(\mathrm{dd}, J=13.9 \mathrm{~Hz}, J=3.6 \mathrm{~Hz}, 1 \mathrm{H}), 2.90-$ $2.83(\mathrm{~m}, 1 \mathrm{H}), 2.16-2.04(\mathrm{~m}, 1 \mathrm{H}), 1.77-1.68(\mathrm{~m}, 1 \mathrm{H}), 1.44(\mathrm{~s}, 9 \mathrm{H})$, $0.84(\mathrm{~d}, J=6.6 \mathrm{~Hz}, 6 \mathrm{H}) ;{ }^{13} \mathrm{C}\{1 \mathrm{H}\} \mathrm{NMR}\left(300 \mathrm{MHz}, \mathrm{CDCl}_{3}\right) \delta(\mathrm{ppm})$ : $172.7,168.6,156.3,135.5,129.4,129.1,127.6,82.5,58.3,52.0,38.3$, $36.8,28.1,25.0,23.3,21.2$; MS ESI- $(+): m / z 361[\mathrm{M}+\mathrm{H}]^{+}, 337,305$, 259; HRMS ESI-(+): calcd for $\mathrm{C}_{20} \mathrm{H}_{28} \mathrm{~N}_{2} \mathrm{O}_{4}[\mathrm{M}+\mathrm{H}]^{+} 361.2127$, found 361.2127.

(S)-tert-Butyl 2-((S)-4-Isopropyl-2,5-dioxoimidazolidin-1-yl)propanoate $2 b$ (Table 2, Entry 2). The reaction scale was $1.49 \mathrm{mmol}$; (175.2 mg, 43\% yield). Mixture of diastereoisomers (maj.:min. 57:43). Colorless oil, $[\alpha]_{\mathrm{D}}^{28}+0.40\left(c=2.0, \mathrm{CHCl}_{3}\right) ;{ }^{1} \mathrm{H}$ NMR $(300 \mathrm{MHz}$, $\left.\mathrm{CDCl}_{3}\right) \delta(\mathrm{ppm}): 6.57-6.55(\mathrm{~m}, 1 \mathrm{H}), 4.66-4.60(\mathrm{~m}, 1 \mathrm{H}, \mathrm{maj}$. and min.), 3.93-3.91 (m, 1H, maj. and $\min$.), $2.25-2.21$ (m, 1H, maj. and $\min$.), 1.54 (d, $J=7.3 \mathrm{~Hz}, 3 \mathrm{H}$, maj.), 1.52 (d, $J=7.3 \mathrm{~Hz}, 3 \mathrm{H}, \min$.), 1.43 (s, $1 \mathrm{H}$, maj.), 1.42 (s, $1 \mathrm{H}, \mathrm{min}$.), 1.05 (d, $J=7.0 \mathrm{~Hz}, 3 \mathrm{H}$, maj.), 1.04 (d, $J=7.0 \mathrm{~Hz}, 3 \mathrm{H}, \mathrm{min}.), 0.95-0.92(\mathrm{~m}, 3 \mathrm{H}$, maj. and $\min .) ;{ }^{13} \mathrm{C}\{1 \mathrm{H}\}$ $\operatorname{NMR}\left(300 \mathrm{MHz}, \mathrm{CDCl}_{3}\right) \delta$ (ppm): maj.: 173.1, 168.7, 157.8, 82.6, 62.6, 48.9, 30.6, 28.2, 19.2, 16.4, 15.1; min.: 173.1, 168.7, 157.7, 82.6, 62.7, 48.9, 30.6, 28.2, 19.1, 16.3, 15.1; MS ESI-(+): $m / z 271[\mathrm{M}+\mathrm{H}]^{+}, 247$, 215, 197, 169; HRMS ESI- $(+)$ : calcd for $\mathrm{C}_{13} \mathrm{H}_{22} \mathrm{~N}_{2} \mathrm{O}_{4}[\mathrm{M}+\mathrm{Na}]^{+}$ 293.1477, found 293.1474.

(S)-tert-Butyl 2-(4,4-Dimethyl-2,5-dioxoimidazolidin-1-yl)-4(methylthio)butanoate 2c (Table 2, Entry 3). The reaction scale was $0.86 \mathrm{mmol}\left(161.9 \mathrm{mg}, 60 \%\right.$ yield). Waxy white solid, $\mathrm{mp} 83-85^{\circ} \mathrm{C}$, $[\alpha]_{\mathrm{D}}^{28}-8.82\left(c=4.2, \mathrm{CHCl}_{3}\right) ;{ }^{1} \mathrm{H} \mathrm{NMR}\left(300 \mathrm{MHz}, \mathrm{CDCl}_{3}\right) \delta(\mathrm{ppm})$ : $6.21(\mathrm{~s}, 1 \mathrm{H}), 4.69(\mathrm{t}, J=7.3 \mathrm{~Hz}, 1 \mathrm{H}), 2.54-2.36(\mathrm{~m}, 4 \mathrm{H}), 2.08(\mathrm{~s}, 3 \mathrm{H})$, $1.45,1.44$, and $1.43\left(\mathrm{~s} \times 3,15 \mathrm{H}, 2 \times \mathrm{CH}_{3}\right.$ and $\left.t-\mathrm{Bu}\right) ;{ }^{13} \mathrm{C}\{1 \mathrm{H}\} \mathrm{NMR}$ $\left(300 \mathrm{MHz}, \mathrm{CDCl}_{3}\right) \delta(\mathrm{ppm}): 177.0,167.8,156.0,82.7,58.8,52.2,31.1$, 28.1, 28.0, 25.1, 15.5; MS ESI-(+): $m / z 317[\mathrm{M}+\mathrm{H}]^{+}, 261,243,215$, 167; HRMS ESI-(+): calcd for $\mathrm{C}_{14} \mathrm{H}_{24} \mathrm{~N}_{2} \mathrm{O}_{4} \mathrm{~S}[\mathrm{M}+\mathrm{H}]^{+} 317.1535$, found 317.1533 .

(S)-tert-Butyl 3-(4-(4-tert-Butoxybenzyl)-2,5-dioxoimidazolidin-1yl)propanoate $2 d$ (Table 2, Entry 4). The reaction scale was $0.83 \mathrm{mmol}$ (286 mg, 88\% yield). White solid, $\mathrm{mp} 129-131^{\circ} \mathrm{C},[\alpha]_{\mathrm{D}}^{28}-8.26(c=5.4$, $\left.\mathrm{CHCl}_{3}\right) ;{ }^{1} \mathrm{H}$ NMR $\left(300 \mathrm{MHz}, \mathrm{CDCl}_{3}\right) \delta(\mathrm{ppm}): 7.08(\mathrm{~d}, J=8.3 \mathrm{~Hz}$, $2 \mathrm{H}), 6.94(\mathrm{~d}, J=8.2 \mathrm{~Hz}, 2 \mathrm{H}), 5.45(\mathrm{~s}, 1 \mathrm{H}), 4.21-4.18(\mathrm{~m}, 1 \mathrm{H}), 3.69(\mathrm{t}, J$ $=6.5 \mathrm{~Hz}, 2 \mathrm{H}), 3.21(\mathrm{dd}, 13.9 \mathrm{~Hz}, J=2.7 \mathrm{~Hz}, 1 \mathrm{H}), 2.83-2.76(\mathrm{~m}, 1 \mathrm{H})$, $2.46(\mathrm{t}, J=7.8 \mathrm{~Hz}, 2 \mathrm{H}), 1.43(\mathrm{~s}, 9 \mathrm{H}), 1.33(\mathrm{~s}, 9 \mathrm{H}) ;{ }^{13} \mathrm{C}\{1 \mathrm{H}\} \mathrm{NMR}$ $\left(300 \mathrm{MHz}, \mathrm{CDCl}_{3}\right) \delta(\mathrm{ppm}): 173.1,170.1,156.9,155.2,130.1,124.8$, 81.4, 79.0, 58.7, 37.7, 34.8, 33.8, 29.2, 28.4; MS ESI-(+): $\mathrm{m} / z 391[\mathrm{M}+$ $\mathrm{H}]^{+}, 335,279,261$; HRMS ESI- $(+)$ : calcd for $\mathrm{C}_{21} \mathrm{H}_{30} \mathrm{~N}_{2} \mathrm{O}_{5}[\mathrm{M}+\mathrm{H}]^{+}$ 391.2233 , found 391.2231 .

(S)-Methyl 2-((S)-4-Benzyl-2,5-dioxoimidazolidin-1-yl)-3-phenylpropanoate 2 e (Table 2, Entry 5). HCl.H-Phe-OMe (0.46 mmol, 2 equiv), $\mathrm{CDI}$ ( 1 equiv) and $\mathrm{K}_{2} \mathrm{CO}_{3}$ (3 equiv) were added to a $5 \mathrm{~mL}$ stainless steel milling jar with two stainless steel milling balls. The reactants were milled in a vibratory ball-mill at $30 \mathrm{~Hz}$ for $2 \mathrm{~h}$. Water was then added to the reaction mixture, and the desired compound $2 \mathbf{e}$ precipitated. The precipitate was recovered by filtration $(47.1 \mathrm{mg}, 58 \%$ yield). CAS $[1634670-17-9] .{ }^{46}$ White solid, mp $142-144{ }^{\circ} \mathrm{C},[\alpha]_{\mathrm{D}}^{28}-$ $9.41\left(c=5.1, \mathrm{CHCl}_{3}\right) ;{ }^{1} \mathrm{H}$ NMR $\left(300 \mathrm{MHz}, \mathrm{CDCl}_{3}\right) \delta(\mathrm{ppm}): 7.31-$ $7.09(\mathrm{~m}, 10 \mathrm{H}), 5.19(\mathrm{~s}, 1 \mathrm{H}), 4.06(\mathrm{dd}, J=10.7 \mathrm{~Hz}, J=3.4 \mathrm{~Hz}, 1 \mathrm{H}), 3.79$ $(\mathrm{s}, 3 \mathrm{H}), 3.50-3.46(\mathrm{~m}, 1 \mathrm{H}), 3.06(\mathrm{dd}, \mathrm{J}=13.9 \mathrm{~Hz}, \mathrm{~J}=3.11 \mathrm{~Hz}, 3 \mathrm{H}), 2.14$ $(\mathrm{dd}, J=13.8 \mathrm{~Hz}, J=10.7 \mathrm{~Hz}, 1 \mathrm{H}) ;{ }^{13} \mathrm{C}\{1 \mathrm{H}\} \mathrm{NMR}\left(300 \mathrm{MHz}, \mathrm{CDCl}_{3}\right) \delta$ (ppm): 172.4, 169.1, 155.7, 136.6, 135.8, 129.3, 129.2, 129.1, 128.8, $127.6,127.2,58.3,53.3,53.1,38.4,34.3$; MS ESI- $(+): m / z 416[\mathrm{M}+\mathrm{Na}$ $+\mathrm{ACN}]^{+}, 375[\mathrm{M}+\mathrm{Na}]^{+}, 353[\mathrm{M}+\mathrm{H}]^{+}, 322,293$.

General Procedure for the Synthesis of 5-Substituted-3(methoxycarbonyl)alkyl-hydantoins (Method B) (Compounds 5ae). Dipeptide 3 (1 equiv) and CDI (2 equiv) were added to a $12 \mathrm{~mL}$ stainless steel milling jar with 25 stainless steel milling balls $(5 \mathrm{~mm}$ diameter). The reactants were milled for $2 \mathrm{~h}$ at $450 \mathrm{rpm}$. Dichloromethane $(2 \mathrm{~mL})$ was added to the reaction mixture, and the organic layer was washed three times with $10 \%$ aq. citric acid and brine, dried over anhydrous $\mathrm{MgSO}_{4}$, and concentrated in vacuo.

General Procedure for the Synthesis of 5-Substituted-3(methoxycarbonyl)alkyl-hydantoins (Method in Solution) (Compounds $5 c$, $5 e$, and $5 f$ ). A solution of dipeptide TFA salts $3 \mathrm{c}, 3 \mathrm{e}$, and $3 \mathrm{f}$ 
(100 mg, 1 equiv) in $\mathrm{CH}_{2} \mathrm{Cl}_{2}(3 \mathrm{~mL})$ with DIPEA (1 equiv) was added dropwise into a solution of $\mathrm{CDI}$ (1.2 equiv) in $\mathrm{CH}_{2} \mathrm{Cl}_{2}(3 \mathrm{~mL})$ at $0{ }^{\circ} \mathrm{C}$. After the addition was complete $(30 \mathrm{~min})$, the reaction was stirred for $3 \mathrm{~h}$ at room temperature. Reaction workup was performed as previously described for milling conditions.

(S)-Methyl 2-((S)-4-Benzyl-2,5-dioxoimidazolidin-1-yl)-4-methylpentanoate 5 a (Table 3, Entry 1). The reaction scale was $0.62 \mathrm{mmol}$ (162.5 mg, 82\% yield). The crude was purified by column chromatography (linear gradient of EtOAc in cyclohexane from 0 to $20 \%$ ). Sticky coloress oil, $[\alpha]_{\mathrm{D}}^{28}-1.45\left(c=5.6, \mathrm{CHCl}_{3}\right) ;{ }^{1} \mathrm{H}$ NMR $(300 \mathrm{MHz}$, $\left.\mathrm{CDCl}_{3}\right) \delta(\mathrm{ppm}): 7.36-7.20(\mathrm{~m}, 5 \mathrm{H}), 5.32(\mathrm{~s}, 1 \mathrm{H}), 4.69$ (dd, $J=$ $11.6 \mathrm{~Hz}, J=4.3 \mathrm{~Hz}, 1 \mathrm{H}), 4.32(\mathrm{ddd}, J=8.6 \mathrm{~Hz}, J=3.8 \mathrm{~Hz}, J=1.3 \mathrm{~Hz}$, $1 \mathrm{H}), 3.73(\mathrm{~s}, 3 \mathrm{H}), 3.29(\mathrm{dd}, J=14.0 \mathrm{~Hz}, J=3.8 \mathrm{~Hz}, 1 \mathrm{H}), 2.88(\mathrm{dd}, J=$ $14.0 \mathrm{~Hz}, J=8.7 \mathrm{~Hz}, 1 \mathrm{H}), 2.22-2.13(\mathrm{~m}, 1 \mathrm{H}), 1.84-1.75(\mathrm{~m}, 1 \mathrm{H}), 1.17-$ $1.10(\mathrm{~m}, 1 \mathrm{H}), 0.86(\mathrm{~d}, J=6.5 \mathrm{~Hz}, 6 \mathrm{H}) ;{ }^{13} \mathrm{C}\{1 \mathrm{H}\} \mathrm{NMR}(300 \mathrm{MHz}$, $\left.\mathrm{CDCl}_{3}\right) \delta(\mathrm{ppm}): 171.9,169.3,155.4,134.4,128.7,128.3,126.8,57.5$, 52.1, 50.4, 37.2, 35.9, 24.1, 22.5, 20.4; MS ESI- $(+): m / z 319[\mathrm{M}+\mathrm{H}]^{+}$, 287, 259; HRMS ESI-(+): calcd for $\mathrm{C}_{17} \mathrm{H}_{22} \mathrm{~N}_{2} \mathrm{O}_{4}[\mathrm{M}+\mathrm{H}]^{+} 319.1658$, found 319.1661 .

(R)-Methyl 2-((S)-4-Benzyl-2,5-dioxoimidazolidin-1-yl)-3-methylbutanoate $5 b$ (Table 3, Entry 2). The reaction scale was $0.25 \mathrm{mmol}$ ( $53.3 \mathrm{mg}, 70 \%$ yield). The product was recovered by precipitation from $10 \%$ aq. citric acid. Colorless oil, $[\alpha]_{\mathrm{D}}^{28}+1.05\left(c=2.0, \mathrm{CHCl}_{3}\right) ;{ }^{1} \mathrm{H}$ NMR $\left(300 \mathrm{MHz}, \mathrm{CDCl}_{3}\right) \delta(\mathrm{ppm}): 7.34-7.20(\mathrm{~m}, 5 \mathrm{H}), 5.68(\mathrm{~s}, 1 \mathrm{H}), 4.33$ $(\mathrm{d}, J=3.0 \mathrm{~Hz}, 1 \mathrm{H}), 4.30(\mathrm{~d}, J=6.0 \mathrm{~Hz}, 1 \mathrm{H}), 3.70(\mathrm{~s}, 3 \mathrm{H}), 3.29(\mathrm{dd}, J=$ $14.0 \mathrm{~Hz}, J=3.8 \mathrm{~Hz}, 1 \mathrm{H}), 2.86(\mathrm{dd}, J=14.0 \mathrm{~Hz}, J=8.6 \mathrm{~Hz}, 1 \mathrm{H}), 2.65-$ $2.57(\mathrm{~m}, 1 \mathrm{H}), 1.04(\mathrm{~d}, J=6.7 \mathrm{~Hz}, 3 \mathrm{H}), 0.72(\mathrm{~d}, J=6.8 \mathrm{~Hz}, 3 \mathrm{H}) ;{ }^{13} \mathrm{C}\{1 \mathrm{H}\}$ $\mathrm{NMR}\left(300 \mathrm{MHz}, \mathrm{CDCl}_{3}\right) \delta(\mathrm{ppm}): 172.9,169.3,156.7,135.4,129.7$, 129.3, 127.8, 58.6, 58.4, 52.8, 38.3, 28.4, 21.1, 19.5; MS ESI-(+): $m / z$ $305[\mathrm{M}+\mathrm{H}]^{+}, 273,245$; HRMS ESI- $(+)$ : calcd for $\mathrm{C}_{16} \mathrm{H}_{20} \mathrm{~N}_{2} \mathrm{O}_{4}[\mathrm{M}+$ $\mathrm{H}]^{+}$305.1501, found 305.1502.

(S)-Methyl 2-((S)-4-Benzyl-2,5-dioxoimidazolidin-1-yl)propanoate 5c (Table 3, Entry 3). Dipeptide 3c was used as a hydrochloric salt. The reaction scale was $0.87 \mathrm{mmol}(137.0 \mathrm{mg}, 57 \%$ yield $)$. White solid, $\mathrm{mp}$ 96-97.7 ${ }^{\circ} \mathrm{C},[\alpha]_{\mathrm{D}}^{24}-149\left(c=1.53, \mathrm{CHCl}_{3}\right) ;{ }^{1} \mathrm{H}$ NMR $(300 \mathrm{MHz}$, $\left.\mathrm{CDCl}_{3}\right) \delta(\mathrm{ppm}): 7.31-7.18(\mathrm{~m}, 5 \mathrm{H}), 6.07(\mathrm{~s}, 1 \mathrm{H}), 4.68(\mathrm{q}, J=7.2 \mathrm{~Hz}$, $1 \mathrm{H}), 4.30-4.27(\mathrm{~m}, 1 \mathrm{H}), 3.72(\mathrm{~s}, 1 \mathrm{H}), 3.26(\mathrm{dd}, J=13.9 \mathrm{~Hz}, J=3.7 \mathrm{~Hz}$ $1 \mathrm{H}), 2.92-2.87(\mathrm{~m}, 1 \mathrm{H}), 1.46(\mathrm{~d}, J=7.3 \mathrm{~Hz}, 3 \mathrm{H}) ;{ }^{13} \mathrm{C}\{1 \mathrm{H}\} \mathrm{NMR}$ $\left(300 \mathrm{MHz}, \mathrm{CDCl}_{3}\right) \delta(\mathrm{ppm}): 172.5,169.9,156.5,135.0,129.5,128.8$, 127.4, 58.3, 52.8, 47.8, 37.8, 14.5; MS ESI-(+): $m / z 277[\mathrm{M}+\mathrm{H}]^{+}, 245$, 217; HRMS ESI- $(+)$ : calcd for $\mathrm{C}_{14} \mathrm{H}_{17} \mathrm{~N}_{2} \mathrm{O}_{4}[\mathrm{M}+\mathrm{H}]^{+} 277.1188$, found 277.1189.

(S)-Methyl 2-((S)-4-(2-(Benzyloxy)-2-oxoethyl)-2,5-dioxoimidazolidin-1-yl)-4-(methylthio)butanoate 5d (Table 3, Entry 4). Dipeptide 3d was as a hydrochloric salt. The reaction scale was $0.25 \mathrm{mmol}$ (74.5 mg, 76\% yield). Sticky colorless oil, $[\alpha]_{\mathrm{D}}^{28}-3.60\left(c=5.2, \mathrm{CHCl}_{3}\right)$; ${ }^{1} \mathrm{H}$ NMR (300 MHz, $\mathrm{CDCl}_{3}$ ) $\delta(\mathrm{ppm}): 7.45-7.17(\mathrm{~m}, 5 \mathrm{H}), 6.50$ (s, $1 \mathrm{H}), 5.15(\mathrm{~s}, 2 \mathrm{H}), 4.89-4.85(\mathrm{~m}, 1 \mathrm{H}), 4.40-4.37(\mathrm{~m}, 1 \mathrm{H}), 3.72$ $(\mathrm{s}, 1 \mathrm{H}), 3.08-3.02(\mathrm{~m}, 1 \mathrm{H}), 2.75-2.44(\mathrm{~m}, 5 \mathrm{H}), 2.06(\mathrm{~s}, 3 \mathrm{H}) ;{ }^{13} \mathrm{C}\{1 \mathrm{H}\}$ NMR $\left(300 \mathrm{MHz}, \mathrm{CDCl}_{3}\right) \delta(\mathrm{ppm}): 172.5,170.4,169.5,156.5,135.4$, 129.0, 128.9, 128.7, 67.6, 53.7, 53.2, 51.9, 36.7, 31.1, 27.6, 15.6; MS ESI-(+): $m / z 395[\mathrm{M}+\mathrm{H}]^{+}, 363,257$. HRMS ESI-(+): calcd for $\mathrm{C}_{16} \mathrm{H}_{20} \mathrm{~N}_{2} \mathrm{O}_{4}[\mathrm{M}+\mathrm{H}]^{+}$305.1501, found 305.1502.

(S)-Methyl 2-((S)-4-Isopropyl-2,5-dioxoimidazolidin-1-yl)propanoate $5 e$ (Table 3, Entry 5). The reaction scale was $0.32 \mathrm{mmol}$ (56.9 $\mathrm{mg}$, 78\% yield). The crude was recovered either by column filtration on silica gel (EtOAc 100\%) or precipitated by Me-THF. White solid, mp $160-162{ }^{\circ} \mathrm{C},[\alpha]_{\mathrm{D}}^{28}+2.40\left(c=5.4, \mathrm{CHCl}_{3}\right) ;{ }^{1} \mathrm{H}$ NMR $\left(300 \mathrm{MHz}, \mathrm{CDCl}_{3}\right) \delta(\mathrm{ppm}): 5.82(\mathrm{~s}, 1 \mathrm{H}), 4.75(\mathrm{q}, J=7.3 \mathrm{~Hz}, 1 \mathrm{H}), 3.97$ $(\mathrm{dd}, J=1.2 \mathrm{~Hz}, J=3.6 \mathrm{~Hz}, 1 \mathrm{H}), 3.74(\mathrm{~s}, 1 \mathrm{H}), 2.30-2.22(\mathrm{~m}, 1 \mathrm{H}), 1.61$ $(\mathrm{d}, J=7.3 \mathrm{~Hz}, 3 \mathrm{H}), 1.05(\mathrm{~d}, J=7.0 \mathrm{~Hz}, 3 \mathrm{H}), 0.95(\mathrm{~d}, J=6.8 \mathrm{~Hz}, 3 \mathrm{H})$; ${ }^{13} \mathrm{C}\{1 \mathrm{H}\}$ NMR $\left(300 \mathrm{MHz}, \mathrm{CDCl}_{3}\right) \delta(\mathrm{ppm}): 172.9,170.2,157.1,62.5$, 53.0, 48.2, 30.6, 19.2, 16.1, 15.1; MS ESI-(+): $m / z 229[\mathrm{M}+\mathrm{H}]^{+}, 197$, 169; IR $\left(\mathrm{cm}^{-1}\right) 3299,2964,1684,1432,1225,1085$; HRMS ESI-(+): calcd for $\mathrm{C}_{10} \mathrm{H}_{16} \mathrm{~N}_{2} \mathrm{O}_{4}[\mathrm{M}+\mathrm{H}]^{+} 229.1188$, found 229.1188.

(S)-2-((S)-4-Benzyl-2,5-dioxoimidazolidin-1-yl)propanamide $5 f$ (Table 3, Entry 6). Only the peaks corresponding to hydantoin are described. The reaction scale was $0.29 \mathrm{mmol}\left(22.1 \mathrm{mg}, 29 \%{ }^{1} \mathrm{H}\right.$ NMR yield). White solid. ${ }^{1} \mathrm{H}$ NMR (300 MHz, DMSO- $\left.d_{6}\right) \delta(\mathrm{ppm}): 8.32$ $(\mathrm{s}, 1 \mathrm{H}), 7.26-7.07(\mathrm{~m}, 5 \mathrm{H}), 4.30(\mathrm{t}, J=4.4 \mathrm{~Hz}, 1 \mathrm{H}), 4.13(\mathrm{q}, J=7.4 \mathrm{~Hz}$,
$1 \mathrm{H}), 2.95(\mathrm{~d}, J=4.7 \mathrm{~Hz}, 2 \mathrm{H}), 1.08(\mathrm{~d}, J=7.3 \mathrm{~Hz}, 3 \mathrm{H}) ;{ }^{13} \mathrm{C}\{1 \mathrm{H}\} \mathrm{NMR}$ $\left(300 \mathrm{MHz}, \mathrm{DMSO}-d_{6}\right) \delta(\mathrm{ppm}): 173.0,170.6,156.1,129.9,128.1$, 126.8, 56.7, 48.2, 36.4, 14.0; MS ESI- $(+): m / z 262[\mathrm{M}+\mathrm{H}]^{+}, 245,217$; HRMS ESI-(+): calcd for $\mathrm{C}_{13} \mathrm{H}_{15} \mathrm{~N}_{3} \mathrm{O}_{3}[\mathrm{M}+\mathrm{H}]^{+}$262.1192, found 262.1194 .

\section{AUTHOR INFORMATION}

\section{Corresponding Author}

*E-mail: evelina.colacino@umontpellier.fr. Tel.: +33 (0)4 6714 42 85. Fax: +33 (0)467 144866.

\section{Notes}

The authors declare no competing financial interest.

\section{ACKNOWLEDGMENTS}

L.K. is grateful to the Ministère de l'Education Nationale, de l'Enseignement Supérieure et de la Recherche (MENR) for the Ph.D. grant. L.G., E.C., F.L., and J.M. acknowledge also the support from Centre National pour la Recherche Scientifique (CNRS) and ENSCM. I.H. is supported by the Croatian Science Foundation under project number UIP-2014-09-4744. R.M.F., J.M.C., and J.S.S. gratefully thank the Agence Nationale de la Recherche for financial support (ANR JCJC: ANR-12-JS070008-01) and the support from CNRS and ENSCM.

\section{REFERENCES}

(1) Meusel, M.; Gutschow, M. Org. Prep. Proced. Int. 2004, 36, 391443

(2) Xiao, X.-y.; Ngu, K.; Chao, C.; Patel, D. V. J. Org. Chem. 1997, 62, $6968-6973$.

(3) Dylag, T.; Zygmunt, M.; Maciag, D.; Handzlik, J.; Bednarski, M.; Filipek, B.; Kiec-Kononowicz, K. Eur. J. Med. Chem. 2004, 39, 10131027.

(4) Handzlik, J.; Bajda, M.; Zygmunt, M.; Maciag, D.; Dybala, M.; Bednarski, M.; Filipek, B.; Malawska, B.; Kiec-Kononowicz, K. Bioorg. Med. Chem. 2012, 20, 2290-2303.

(5) Stilz, H. U.; Guba, W.; Jablonka, B.; Just, M.; Klingler, O.; Koenig, W.; Wehner, V.; Zoller, G. J. Med. Chem. 2001, 44, 1158-1176.

(6) Buntain, I. G.; Suckling, C. J.; Wood, H. C. S. J. Chem. Soc., Perkin Trans. 1 1988, 3175-82.

(7) Howie, C.; Suckling, C. J.; Wood, H. C. S. J. Chem. Soc., Perkin Trans. 1 1990, 3129-35.

(8) Abo-Dya, N. E.; Biswas, S.; Basak, A.; Avan, I.; Alamry, K. A.; Katritzky, A. R. J. Org. Chem. 2013, 78, 3541-3552.

(9) Verhelst, S. H. L.; Witte, M. D.; Arastu-Kapur, S.; Fonovic, M.; Bogyo, M. ChemBioChem 2006, 7, 943-950.

(10) Savrda, J.; Chertanova, L.; Wakselman, M. Tetrahedron 1994, 50, 5309-22.

(11) Danger, G.; Boiteau, L.; Cottet, H.; Pascal, R. J. Am. Chem. Soc. 2006, 128, 7412-7413.

(12) Ohmoto, K.; Yamamoto, T.; Okuma, M.; Horiuchi, T.; Imanishi, H.; Odagaki, Y.; Kawabata, K.; Sekioka, T.; Hirota, Y.; Matsuoka, S.; Nakai, H.; Toda, M.; Cheronis, J. C.; Spruce, L. W.; Gyorkos, A.; Wieczorek, M. J. Med. Chem. 2001, 44, 1268-1285.

(13) Wehner, V.; Blum, H.; Kurz, M.; Stilz, H. U. Synthesis 2002, 2002, 2023-2036.

(14) Da Settimo, F.; Primofiore, G.; La Motta, C.; Salerno, S.; Novellino, E.; Greco, G.; Lavecchia, A.; Laneri, S.; Boldrini, E. Bioorg. Med. Chem. 2005, 13, 491-499. 
(15) Takeuchi, Y.; Kirihara, K.; Shibata, N.; Kirk, K. L. Chem. Commun. (Cambridge, U. K.) 2000, 785-786.

(16) Tzvetkov, N. T.; Euler, H.; Mueller, C. E. Beilstein J. Org. Chem. 2012, 8, 1584-1593.

(17) Imanzadeh, G.; Rezaee-Gatar, S. Arkivoc 2015, 5, 121-133.

(18) Handzlik, J.; Maciag, D.; Kubacka, M.; Mogilski, S.; Filipek, B.; Stadnicka, K.; Kiec-Kononowicz, K. Bioorg. Med. Chem. 2008, 16, 59825998.

(19) Abdulrahman, L. Q.; Mohammed, M. A.; Qasim, M. L. Int. Res. J. Pharm. 2014, 5, 155-158.

(20) Ozturk, S.; Yildirim, A.; Cetin, M. Appl. Surf. Sci. 2013, 265, 895903.

(21) Adib, M.; Hosein Sayahi, M.; Behnam, B.; Sheibani, E. Monatsh. Chem. 2006, 137, 191-196.

(22) Marandi, G.; Maghsoodlou, M. T.; Hazeri, N.; Heydari, R.; Habibi-Khorassani, S. M.; Torbati, N. A.; Sajadikhah, S. S.; Saravani, D.; Rakhshanipour, M.; Gholamipour, S.; Rostami-Charati, F.; Skelton, B. W.; Makha, M.; Zare, Z.; Lashkari, M. Heteroat. Chem. 2011, 22, 630639.

(23) Liu, H.; Yang, Z.; Pan, Z. Org. Lett. 2014, 16, 5902-5905.

(24) Chaubet, G.; Cazals, G.; Lebrun, A.; Martinez, J.; Parrot, I. Synlett 2014, 25, 574-578.

(25) Jenhi, A.; Lavergne, J. P.; Rolland, M.; Martinez, J.; Hasnaoui, A. Synth. Commun. 2001, 31, 1707-1714.

(26) Wehner, V.; Stilz, H.-U.; Osipov, S. N.; Golubev, A. S.; Sieler, J.; Burger, K. Tetrahedron 2004, 60, 4295-4302.

(27) Konnert, L.; Gauliard, A.; Lamaty, F.; Martinez, J.; Colacino, E. ACS Sustainable Chem. Eng. 2013, 1, 1186-1191.

(28) Konnert, L.; Lamaty, F.; Martinez, J.; Colacino, E. J. Org. Chem. 2014, 79, 4008-4017.

(29) Lanzillotto, M.; Konnert, L.; Lamaty, F.; Martinez, J.; Colacino, E. ACS Sustainable Chem. Eng. 2015, 3, 2882-2889.

(30) Konnert, L.; Reneaud, B.; de Figueiredo, R. M.; Campagne, J.-M.; Lamaty, F.; Martinez, J.; Colacino, E. J. Org. Chem. 2014, 79, 1013210142 .

(31) Konnert, L.; Dimassi, M.; Gonnet, L.; Lamaty, F.; Martinez, J.; Colacino, E. RSC Adv. 2016, 6, 36978-36986.

(32) Strukil, V.; Gracin, D.; Magdysyuk, O. V.; Dinnebier, R. E.; Friscic, T. Angew. Chem., Int. Ed. 2015, 54, 8440-8443.

(33) Strukil, V.; Igrc, M. D.; Eckert-Maksic, M.; Friscic, T. Chem. - Eur. J. 2012, 18, 8464-8473.

(34) Strukil, V.; Igrc, M. D.; Fabian, L.; Eckert-Maksic, M.; Childs, S. L.; Reid, D. G.; Duer, M. J.; Halasz, I.; Mottillo, C.; Friscic, T. Green Chem. 2012, 14, 2462-2473.

(35) Tan, D.; Strukil, V.; Mottillo, C.; Friscic, T. Chem. Commun. 2014, $50,5248-5250$.

(36) Kokotos, C. G.; Limnios, D.; Triggidou, D.; Trifonidou, M.; Kokotos, G. Org. Biomol. Chem. 2011, 9, 3386-3395.

(37) Vega-Peñaloza, A.; Sanchez-Antonio, O.; vila-Ortiz, C. G.; Escudero-Casao, M.; Juaristi, E. Asian J. Org. Chem. 2014, 3, 487-496.

(38) Halland, N.; Broenstrup, M.; Czech, J.; Czechtizky, W.; Evers, A.; Follmann, M.; Kohlmann, M.; Schiell, M.; Kurz, M.; Schreuder, H. A.; Kallus, C. J. Med. Chem. 2015, 58, 4839-4844.

(39) Maresca, K. P.; Hillier, S. M.; Femia, F. J.; Keith, D.; Barone, C.; Joyal, J. L.; Zimmerman, C. N.; Kozikowski, A. P.; Barrett, J. A.; Eckelman, W. C.; Babich, J. W. J. Med. Chem. 2009, 52, 347-357.

(40) Grzyb, J. A.; Shen, M.; Yoshina-Ishii, C.; Chi, W.; Brown, R. S.; Batey, R. A. Tetrahedron 2005, 61, 7153-7175.

(41) Granacher, C.; Landolt, H. Helv. Chim. Acta 1927, 10, 799-815.

(42) Chong, P. Y.; Petillo, P. A. Tetrahedron Lett. 1999, 40, 24932496.

(43) Henkel, B. Synthesis of cyclic imide containing peptide products. Patent CA2907521, September 25, 2014.

(44) Nefzi, A.; Ostresch, J. M.; Giulianotti, M.; Houghten, R. A. Tetrahedron Lett. 1998, 39, 8199-8202.

(45) Vazquez, J.; Royo, M.; Albericio, F. Lett. Org. Chem. 2004, 1, 224226.

(46) Wang, G.; Wang, Y.; Wang, L.; Han, L.; Hou, X.; Fu, H.; Fang, H. Bioorg. Med. Chem. 2015, 23, 7359-7365.
(47) Do, J.-L.; Mottillo, C.; Tan, D.; Štrukil, V.; Friščić, T. J. Am. Chem. Soc. 2015, 137, 2476-2479.

(48) Konnert, L.; Dimassi, M.; Gonnet, L.; Lamaty, F.; Martinez, J.; Colacino, E. RSC Adv. 2016, 6, 36978-36986.

(49) Konnert, L.; Gauliard, A.; Lamaty, F.; Martinez, J.; Colacino, E. ACS Sustainable Chem. Eng. 2013, 1, 1186-1191.

(50) Carpino, L. A. J. Am. Chem. Soc. 1993, 115, 4397-8.

(51) Nowick, J. S.; Holmes, D. L.; Noronha, G.; Smith, E. M.; Nguyen, T. M.; Huang, S.-L. J. Org. Chem. 1996, 61, 3929-3934.

(52) Tan, D.; Loots, L.; Friscic, T. Chem. Commun. 2016, 52, 77607781.

(53) Konnert, L.; Reneaud, B.; de Figueiredo, R. M.; Campagne, J.-M.; Lamaty, F.; Martinez, J.; Colacino, E. J. Org. Chem. 2014, 79, 1013210142. 